Article

\title{
Agriculture Management Impacts on Soil Properties and Hydrological Response in Istria (Croatia)
}

\author{
Bogunovic Igor ${ }^{1, * \mathbb{D}}$, Telak Leon Josip ${ }^{1}$ and Pereira Paulo ${ }^{2}$ \\ 1 Faculty of Agriculture, University of Zagreb, 10000 Zagreb, Croatia; ljtelak@agr.hr \\ 2 Environmental Management Laboratory, Mykolas Romeris University, LT-08303 Vilnius, Lithuania; \\ pereiraub@gmail.com \\ * Correspondence: ibogunovic@agr.hr; Tel.: +385-1-2393815
}

Received: 17 December 2019; Accepted: 14 February 2020; Published: 16 February 2020

\begin{abstract}
The objective of this work is to study the effects of traditional land uses (vineyard, cropland, and olive orchard) on soil properties, overland flow, and sediment loss in the Istria region (Croatia), by using simulated rainfall. The results showed that soil bulk density (BD) was significantly higher in cropland plots compared to the vineyard and olive orchard. No differences were observed in soil water content (SWC) and mean weight diameter (MWD). Water stable aggregates (WSA), soil organic matter (SOM), and total nitrogen (TN) were significantly higher in the olive orchard compared to the other land uses. In cropland, during the experiment, we did not identify runoff or soil losses. Runoff (Run) and sediment loss (SL) were significantly higher in the olive orchard compared to the other plots. This was very likely a consequence of tillage practices in vertic soils, the use of herbicides, low vegetation cover, as well as the incorporation of hydrophobic organic matter in the soil matrix. The principal component analysis results showed that factor 1 explained the majority of the runoff and erosion variables. Erosion rates and nutrient losses were substantially different between olive orchard plots, and vineyard and cropland. Factor 2 showed that WSA was inversely related to the available phosphorus, water holding capacity, and sediment concentration. Management practices in the studied area should use minimum tilling frequency to have plant cover and avoid erosion.
\end{abstract}

Keywords: soil erosion; tillage; rainfall simulation; agriculture land management; Mediterranean

\section{Introduction}

Soil erosion is one of the most important causes of land degradation. Non-sustainable agriculture practices increase soil losses and decrease soil fertility, crop yield, and income [1]. The Mediterranean area is affected by long-term human impact that has mainly become unsustainable as a consequence of the proliferation of cash crops. These types of agricultural practices, coupled with the natural characteristics of the regions (e.g., frequent intense rainfalls, vegetation cover, soil type, and steep slopes), are responsible for soil degradation [2-5].

In the Mediterranean area, vineyards have been recognized as one of the land uses more vulnerable to erosion [5,6]. However, high erosion rates were also observed in olive orchards [7] and croplands [8]. Agriculture is the key driver of the soil losses and runoff, regardless of the management [9]. Lack of contour management, intense tillage, machinery-induced compaction, and herbicide application are responsible for high erosion rates [10]. Unsustainable land practices are responsible for soil degradation [11], especially when heavy machinery is used. Compaction decreases water infiltration, and soil and nutrient losses are high [12]. However, tillage is a millenary tradition that can improve, preserve, or deteriorate soil quality [13]. In the Mediterranean, farmers use tillage to reduce water competition, increase water infiltration, and mix soil amendments [14]. Tilled soils are looser, warmer, and the mineralization rate is high. 
Long-term studies are needed to understand the impacts of land-use practices on soil erosion [15-17], especially in areas where such studies are missing as in the Adriatic region of Croatia. The works carried out were mainly focused on areas with different management over time $[8,18,19]$. To our knowledge, no previous research was carried out concerning the impacts of long term traditional agricultural practices in vineyards, croplands, and olive orchards in this area of the Mediterranean. This work aims to study the impact of traditional land uses in three different types of cultures (vineyard, cropland, and olive orchard) in the Istria region (Croatia). The specific objectives is to analyze the effects of land use management on different soil properties and their hydrological response to simulated rainfall.

\section{Materials and Methods}

\subsection{Study Site}

The study was carried out in the northwest area of Istria, west Croatia $\left(45^{\circ} 21^{\prime} \mathrm{N} ; 13^{\circ} 26^{\prime} \mathrm{E}\right)$, at an average elevation of $296 \mathrm{~m}$ above sea level (a.s.l.) (Figure 1). The parent material is composed of carbonate material, and the soil has clay to clay-loam texture, classified as Chromic Luvisols or Cambisol Rhodic (local classification is Terra Rossa) [20]. The climate is Cfa-a hot-summer Mediterranean climate in the Köppen climate classification [21]. The average annual precipitation (1991-2010) is $927.3 \mathrm{~mm}$, ranging from a minimum of $641.2 \mathrm{~mm}$ (2006) to a maximum of $1164.5 \mathrm{~mm}$ (2005). Rainfall is mainly concentrated from September to March with high inter-annual and annual variations. The mean annual temperature is $14.6{ }^{\circ} \mathrm{C}$. Cropland, vineyard, and orchard were the main land-use types in the study area. The area lies on gentle slopes, and this is the reason for the absence of soil and water control practices.

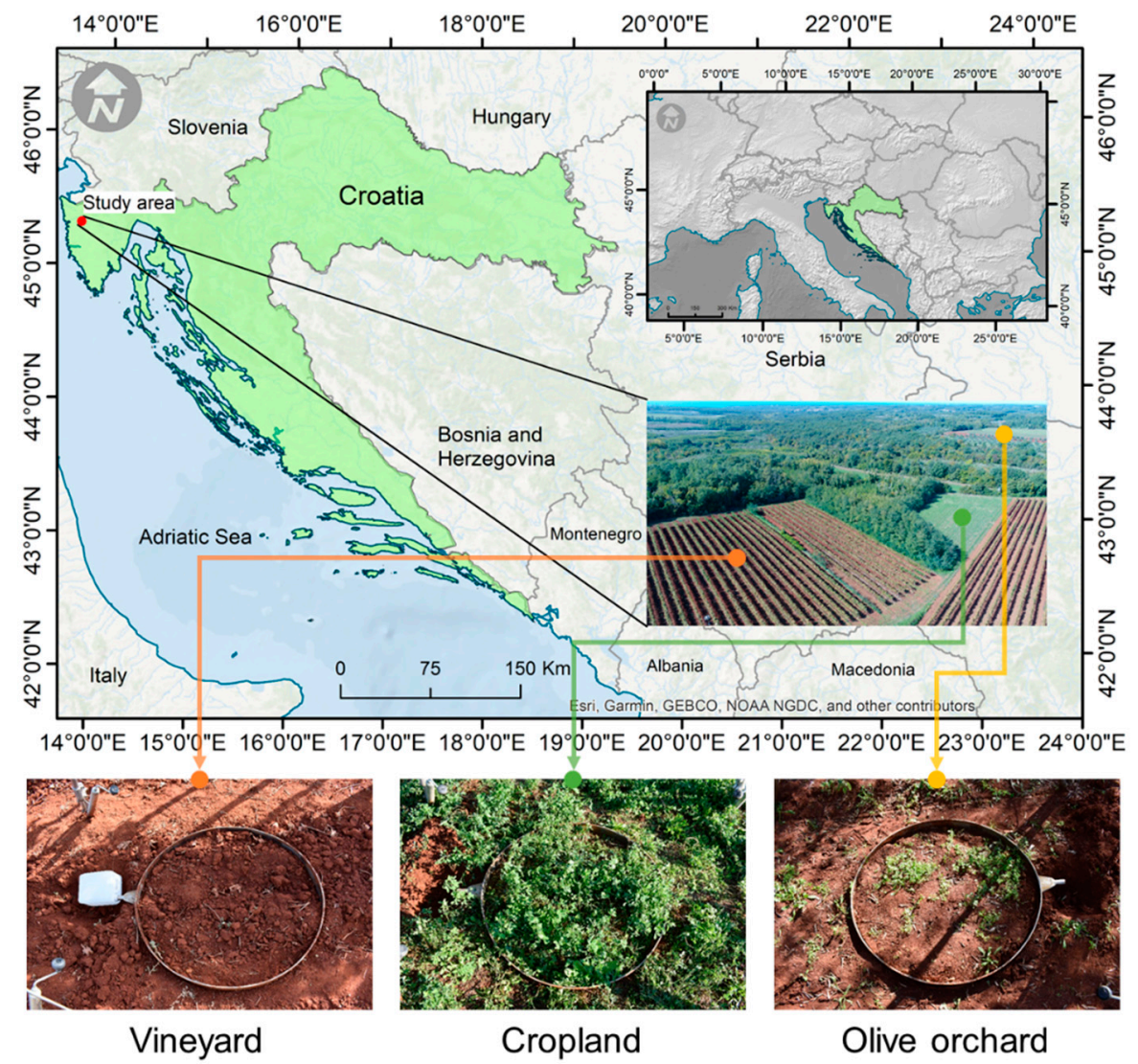

Figure 1. Study area. 


\subsection{Field Experiments and Laboratory Analyses}

Cropland, vineyard, and olive orchard were used as treatments. Prior to the experiment initiation, land-use practices were investigated. The olive orchard is conventionally tilled each spring by disking to a depth of $10 \mathrm{~cm}$. During the late spring, weeds are suppressed using herbicides (glyphosate-based herbicide "Cidokor" in doze $8 \mathrm{~L} \mathrm{ha}^{-1}$ ). After the harvest, olive and grape pomace are returned to the soil. Mineral fertilizer is also added in the spring before the tillage. Vineyards are tilled to $18 \mathrm{~cm}$ depth, 5-6 times per year, in order to keep the soil bare. Here, herbicides are not used since the weeds are suppressed mechanically. Vineyards are fertilized with mineral fertilizers only. Cropland soil for each culture in the rotation is tilled using a disc plow, followed by two passes of roto-harrow, and seedbed preparation before sowing. Herbicides and insecticides are used annually only for cash crops in the rotation. At this land-use, every several years, soils were fertilized with farmyard manure. In the time of measurements, the alfalfa (planted two years before) covered the soil and moved for fodder. In this part of Europe, alfalfa can be used as a source for fodder for 5-7 years, depending on the climate. Cropland was tilled last time in the autumn of 2016.

Each treatment was managed similarly for at least 20 years. At each treatment, a transect was established to carry out the experiments. We selected eight sampling points, separated by six meters, where we sampled soils and carried out rainfall simulation experiments. The rainfall simulation experiments were performed during September 2018 under wet soil conditions with a rainfall simulator (UGT Rainmaker, Muencheberg, Germany), calibrated to reproduce rainstorms of $58 \mathrm{~mm} \mathrm{~h}^{-1}$ rainfall intensity, over $30 \mathrm{~min}$ on the circular plots of $0.785 \mathrm{~m}^{2}$ (metal ring $100 \mathrm{~cm}$ in diameter). We used rainfall parameters based on the research of Biddoccu et al. [22], which observed $93 \%$ of the annual soil loss in a single rainstorm event, as well as the highest soil erosion rates at the rainfall intensity of $59 \mathrm{~mm} \mathrm{~h}^{-1}$. Before each simulation, undisturbed soil samples and soil core samples were taken from $10 \mathrm{~cm}$ downslope of each metal ring. The slope was measured inside the ring area. Time to ponding (TP) and time to runoff (TR) were measured with a chronometer during the rainfall simulations. In each plot $\left(0.785 \mathrm{~m}^{2}\right)$, a photo was taken to measure vegetation cover (VC). The photo was georeferenced using ArcGIS 10.2 software. Subsequently, the \% of pixels with vegetation in relation to the area of the plot was calculated.

Undisturbed samples were used to measure soil water content (SWC) and water holding capacity (WHC) determined using the gravimetric method in natural and wetted core samples [23]. After they dried in an oven at $105^{\circ} \mathrm{C}$ for $48 \mathrm{~h}$, they were weighed to obtain the bulk density (BD) [24]. Additional undisturbed soil samples were collected to determine mean weight diameter (MWD) of soil aggregates, according to Diaz-Zorita [25] and Le Bissonnais [26]. Water stable aggregates (WSA) in sampled soils were determined and calculated by the procedure described in Kemper and Rosenau [27]. Part of these samples was sieved ( $2 \mathrm{~mm}$ mesh) to determine soil chemical properties. Soil organic matter (SOM) content was calculated according to the digestion method [28]. For analyses of available phosphorus $\left(\mathrm{P}_{2} \mathrm{O}_{5}\right)$ in soils and sediments ( $\mathrm{P}$ loss), contents samples were subjected to extraction with ammonium lactate-AL method [29]. $\mathrm{P}_{2} \mathrm{O}_{5}$ content was analyzed using a spectrophotometer (Hach, Germany, model DR/2000) [30]. Total nitrogen (TN) in soils and C (C loss) and N (N loss) in sediments were obtained by a dry-combustion method with vario MACRO CHNS analyzer.

Water contained in plastic canisters (overland flow) were weighed and filtered (with 0.45 micron pore size) to obtain overland flow and sediment yield after drying of the filter paper. The mass of the sediment (SL) was deduced from the mass of overland flow to obtain the water runoff (Run). Sediment concentration (SC) was calculated, dividing the mass of the sediment with the mass of the water in the samples. Dried sediments were milled and passed through $2 \mathrm{~mm}$ mesh as a preparation for the $\mathrm{C}, \mathrm{N}$, and $\mathrm{P}_{2} \mathrm{O}_{5}$ determination.

\subsection{Statistical Analysis}

Before statistical comparisons, data normality was tested using the Kolmogorov-Smirnov test. Data normality and homogeneity of the variances were considered at a $p>0.05$. Among all the variables, 
TP, TR, Run, and SL did not follow the Gaussian distribution. Even after performing logarithmic, square-root, and Box-Cox transformation, normality was not achieved. Therefore, we applied the non-parametric Kruskal-Wallis ANOVA (KW) test to identify differences among plots. For BD, SOM, SWC, WHC, MWD, and WSA, a one-way ANOVA was used to identify significant differences among plots. If significant differences were found, the Tukey HSD post-hoc test was applied. For the other variables, KW test was applied. If significant differences were observed, multiple comparisons of the mean ranks post-hoc test were applied. In all cases, the significant differences were considered at $p<0.05$. A principal component analysis (PCA) was carried out (using the log-transformed data, since the data distributions were closest to normality), based on the correlation matrix, in order to identify correlations among the variables. Statistical analyses were carried out using Statistica 12.0 for windows. Graphics were carried out using the Plotly version 4.9.2 [31].

\section{Results}

\subsection{Vegetation Cover and Soil Properties}

Vegetation cover ranged from $6.19 \%$ in vineyards to $93.68 \%$ in cropland. It was significantly lower in the olive orchard and vineyard compared to the cropland (Table 1). BD and WHC of the soils ranged from 1.14 to $1.37 \mathrm{~g} \mathrm{~cm}^{-3}$ and from $39.7 \%$ to $43.8 \%$, respectively. BD was significantly higher in the cropland than in the other land uses, while WHC was significantly lower in the cropland and olive orchard compared to a vineyard. SWC and MWD varied between $25.2-32.1 \%$ and $2.59-3.27 \mathrm{~mm}$, respectively. In both cases, no significant difference was identified. WSA and SOM ranged from $81.4 \%$ to $92.9 \%$ and from $1.87 \%$ to $3.60 \%$, respectively. WSA was significantly higher in the olive orchard, compared to the vineyard and cropland, while SOM was significantly lower in the vineyard and cropland than in the olive orchard. Soil $\mathrm{P}_{2} \mathrm{O}_{5}$ ranged from 343.6 to $328.2\left(\mathrm{mg} \mathrm{kg}^{-1}\right) \cdot \mathrm{P}_{2} \mathrm{O}_{5}$ values were significantly higher in the vineyard and olive orchard compared to the cropland. Finally, soil TN ranged from $0.10 \%$ to $0.19 \%$. The concentration of TN was significantly lower in vineyard soils compared with the other treatments.

Table 1. Average values of BD, bulk density; WHC, water holding capacity; SWC, soil water content; MWD, mean weight diameter; WSA, water stable aggregates; $\mathrm{SOM}$, soil organic matter; $\mathrm{P}_{2} \mathrm{O}_{5}$, available phosphorous and TN, total nitrogen and one-way and Kruskal-Wallis ANOVA analysis. The effects of soil management on soil properties. Small letters in the column represent the difference in treatment effects at $p<0.05$. ns, not significant at $p<0.05$.

\begin{tabular}{|c|c|c|c|c|c|c|c|c|c|c|}
\hline Treatment & $\begin{array}{c}\text { Slope } \\
\left({ }^{\circ}\right)\end{array}$ & $\begin{array}{l}\text { Vegetation } \\
\text { Cover (\%) }\end{array}$ & $\begin{array}{c}\text { BD } \\
\left(\mathrm{g} \mathrm{cm}^{-3}\right)\end{array}$ & $\begin{array}{c}\text { WHC } \\
(\%)\end{array}$ & $\begin{array}{l}\text { SWC } \\
(\%)\end{array}$ & $\begin{array}{l}\text { MWD } \\
(\mathrm{mm})\end{array}$ & $\begin{array}{l}\text { WSA } \\
(\%)\end{array}$ & $\begin{array}{c}\text { SOM } \\
(\%)\end{array}$ & $\begin{array}{c}\mathrm{P}_{2} \mathrm{O}_{5} \\
\left(\mathrm{mg} \mathrm{kg}^{-1}\right)\end{array}$ & $\begin{array}{l}\text { TN } \\
(\%)\end{array}$ \\
\hline Vineyard & 3.8 & $6.19 c$ & $1.21 \mathrm{~b}$ & $43.8 \mathrm{a}$ & 31.1 & 2.59 & $81.4 \mathrm{~b}$ & $1.87 \mathrm{c}$ & $343.6 \mathrm{a}$ & $0.10 \mathrm{c}$ \\
\hline Cropland & 4.0 & $93.68 \mathrm{a}$ & $1.37 \mathrm{a}$ & $39.7 \mathrm{~b}$ & 28.2 & 2.69 & $88.9 \mathrm{ab}$ & $2.47 \mathrm{~b}$ & $61.9 \mathrm{~b}$ & $0.14 \mathrm{~b}$ \\
\hline Olive orchard & 4.2 & $20.36 \mathrm{~b}$ & $1.14 \mathrm{~b}$ & $40.3 \mathrm{~b}$ & 32.1 & 3.27 & $92.9 \mathrm{a}$ & $3.60 \mathrm{a}$ & $328.2 \mathrm{a}$ & $0.19 \mathrm{a}$ \\
\hline$p$ value & n.s. & $* * *$ & $* * *$ & $* * *$ & n.s. & n.s. & * & $* * *$ & ** & $* * *$ \\
\hline
\end{tabular}

\subsection{Overland Flow}

The effects of soil management on the overland flow properties are summarized in Table 2. TP and TR ranged from 202.8 to $1800 \mathrm{~s}$ and 740 to $1504 \mathrm{~s}$, respectively. In both cases, the olive orchard showed significantly lower values compared to the other plots. No hydrological response was observed in cropland plots. Run and SC varied from 0 to $53.69\left(\mathrm{~m}^{3} \mathrm{ha}^{-1}\right)$ and from 0 to $5.77\left(\mathrm{~g} \mathrm{~kg}^{-1}\right)$, respectively. SL ranged from 0 to $203.9\left(\mathrm{~kg} \mathrm{ha}^{-1}\right)$. Run and SL were always significantly higher in the olive orchard plots than in the vineyard and cropland. SC was significantly lower in the cropland compared to the other land uses. $\mathrm{C}$ loss, $\mathrm{N}$ loss, and $\mathrm{P}$ loss were in all cases significantly higher in the olive orchard (Figure 2). 
Table 2. Average values of time to ponding, time to runoff, runoff, sediment concentration and sediment loss, and one-way and Kruskal-Wallis ANOVA analysis. The effects of soil management on the vegetation cover and the overland flow properties. Small letters in the column represent the difference of treatment effects at $p<0.05$. ${ }^{* * *}$, statistically significant at $p<0.001$.

\begin{tabular}{|c|c|c|c|c|c|}
\hline Treatment & $\begin{array}{c}\text { Time to } \\
\text { Ponding (sec) }\end{array}$ & $\begin{array}{c}\text { Time to } \\
\text { Runoff (sec) }\end{array}$ & $\begin{array}{c}\text { Runoff } \\
\left(\mathrm{m}^{3} h \mathrm{a}^{-1}\right)\end{array}$ & $\begin{array}{c}\text { Sediment } \\
\text { Concentration } \\
\left(\mathrm{g} \mathrm{kg}^{-1}\right)\end{array}$ & $\begin{array}{l}\text { Sediment Loss } \\
\quad\left(\mathrm{kg} \mathrm{ha}^{-1}\right)\end{array}$ \\
\hline Vineyard & $1082.4 \mathrm{ab}$ & $1504.8 \mathrm{ab}$ & $5.57 \mathrm{ab}$ & $5.77 \mathrm{a}$ & $37.8 \mathrm{ab}$ \\
\hline Cropland & 1800 a & $>1800 \mathrm{a}$ & $0.00 \mathrm{~b}$ & $0.00 \mathrm{~b}$ & $0.0 \mathrm{~b}$ \\
\hline Olive orchard & $202.8 \mathrm{~b}$ & $740.1 \mathrm{~b}$ & $53.69 \mathrm{a}$ & $3.96 \mathrm{a}$ & 203.9 a \\
\hline$p$ value & $* * *$ & $* * *$ & $* * *$ & $* * *$ & $* * *$ \\
\hline
\end{tabular}
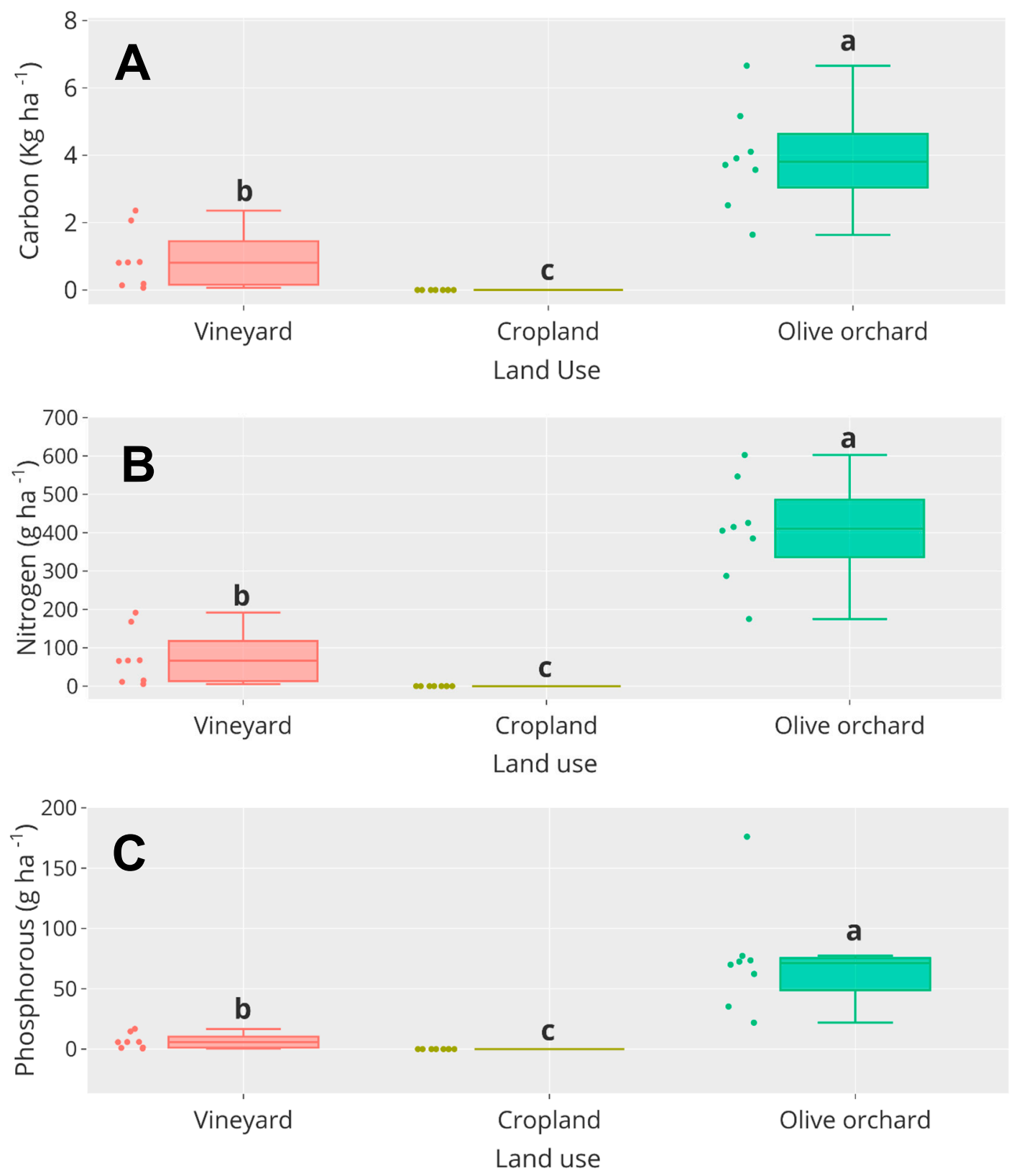

Figure 2. Nutrients loss in runoff: (A) Carbon, (B) Nitrogen, (C) Phosphorus. Different lower case letters represent significant differences at a $p<0.05$. 


\subsection{PCA Analysis}

The first three factors explained $83.98 \%$ of the total variance (Table S1 in Supplementary Material). Factor 1 explained $49.58 \%$, and Factors 2 and 3 explained $24.71 \%$ and $9.96 \%$, respectively, of all variance. Factor 1 had high positive loadings in $\mathrm{BD}, \mathrm{TP}$, and TR, and high negative in MWD, SOM, $\mathrm{P}_{2} \mathrm{O}_{5}, \mathrm{TN}$, Run, SL, C, N, and P loss. Factor 2 had high positive loadings in WHC, and SC and high negative loadings in VC and WSA. Finally, factor 3 had high positive loadings in slope and SWC. The intersection between Factor 1 and Factor 2 shows that BD, TP, and TR are inversely related to the majority of the other variables, especially to Run, N loss, P loss, and SL (Figure 3A). The management practices have different impacts on soil properties and hydrological response in all the treatments. The impact is notably different between the olive orchard and the other treatments. The variability is high in the vineyard and low in cropland (Figure $3 \mathrm{~A}$ ).
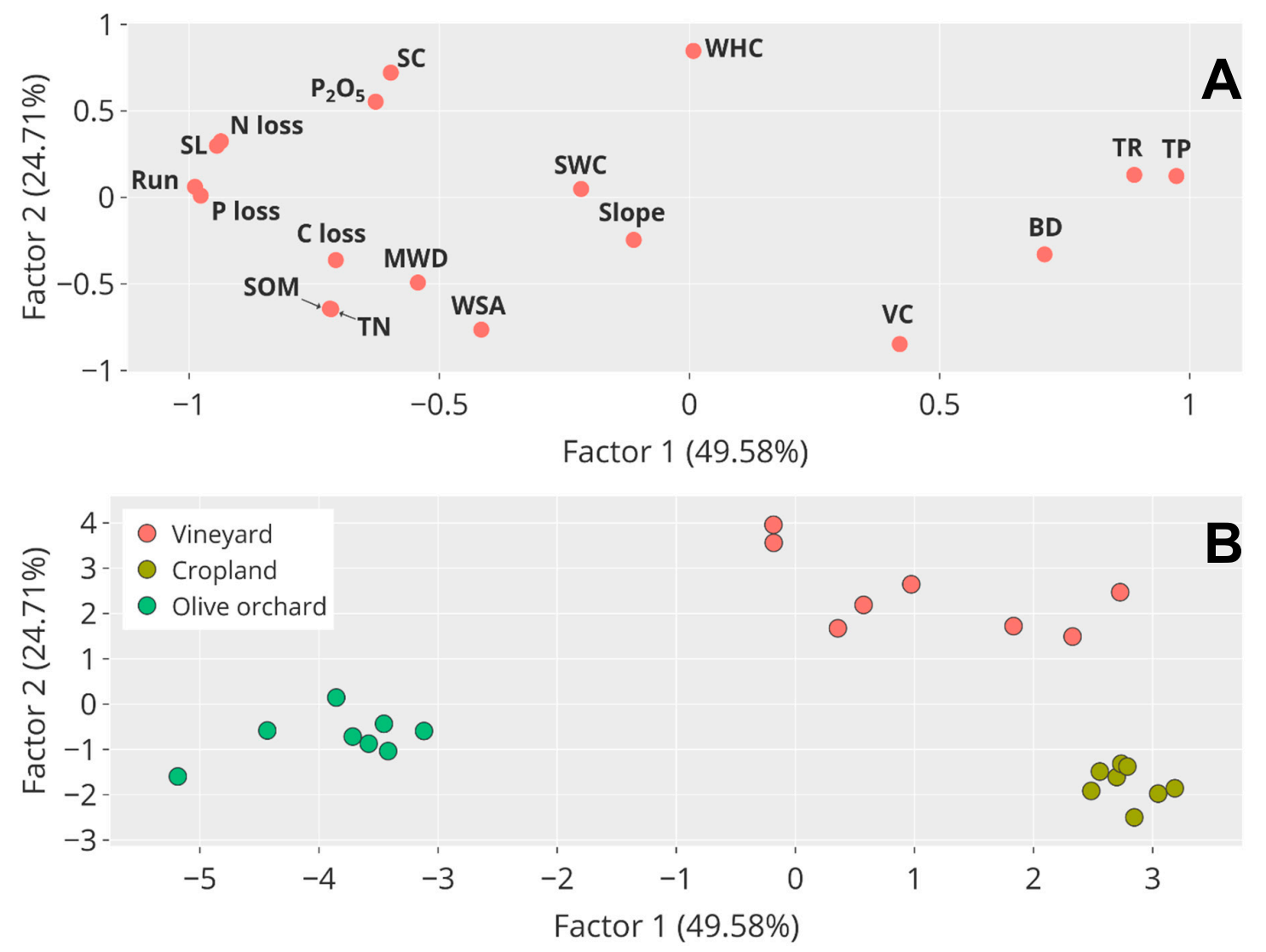

Figure 3. Relation between Factors 1 and 2, (A) Variables and (B) Cases. VC, vegetation cover; BD, bulk density; WHC, water holding capacity; SWC, soil water content; MWD, mean weight diameter; WSA, water stable aggregates; $\mathrm{SOM}$, soil organic matter; $\mathrm{P}_{2} \mathrm{O}_{5}$, available phosphorous; $\mathrm{TN}$, total nitrogen; $\mathrm{TP}$, time to ponding; TR, time to runoff; Run, runoff, SC, sediment concentration; SL, sediment loss; N loss, nitrogen loss, C loss; carbon loss and P loss; phosphorous loss.

\section{Discussion}

The results of this work indicated that the BD was higher in the cropland compared to the vineyard and olive orchard treatments. This was attributed to the fact that tillage in the vineyard and olive orchard were carried out more recently than in the cropland ( 2 years before measurements). It is widely known that tillage reduces, in the short term, topsoil BD [13,32,33]. Natural consolidation and traffic-induced compaction cause the highest soil BD in this study [34]. High values of compaction in cropland soils were observed in previous works [35], although opposite results could also be found [36]. In Ethiopia, Bewket and Stroosnijder [37], on clay and silty soils, reported higher BD in Eucalyptus 
plantation than in cropland soils. In the Mediterranean environment on silty clay loam soil, Celik [38] reported the highest $\mathrm{BD}$ in cropland land-use type.

The MWD can explain the significantly higher WHC on the vineyard compared to the cropland and olive orchard. Although MWD did not show significant differences among treatments, aggregates were small in the vineyard soil. High MWD increases water infiltration [39], while smaller pore sizes increase water retention, and this may explain the high WHC in the vineyard soil [40].

The land use in this study changed soil structural characteristics. Soil compaction, MWD, WSA, and SOM concentration are often related [41]. In the present study, MWD is the highest in the olive orchard and the lowest in the vineyard. This is attributed to high SOM content [42]. The management can explain the reduced MWD, WSA, and SOM in the vineyard and cropland soils. The addition of olive pomace in the olive orchard, increased $\mathrm{SOM}, \mathrm{TN}, \mathrm{P}_{2} \mathrm{O}_{5}$, and WSA [43]. The studied vineyard is subjected to frequent tillage, decreasing WSA, and SOM [9,44]. Cropland and olive orchard management were less managed, decreasing the vulnerability of soils to disaggregation. Reduced tillage increases soil quality (e.g., increase of SOM, MWD, and WSA) as observed by others [43,45].

Soil erosion in the study area depends on the natural soil properties, tillage, herbicides application, vegetation cover, and organic matter properties. The soils of the study area have vertic properties and develop cracks and water preferential flow. It has been highlighted in several works that water infiltration is high in these types of soils [46,47]. Tillage practices reduced infiltration in vertisols as observed elsewhere [48,49], and this may be one of the causes for the high erosion rates in the vineyard and olive orchard plots compared to the cropland (despite the high BD). The measurements carried out in Istria simulated high magnitude storms and showed that the olive orchard could lose as much as $0.2 \mathrm{tha}^{-1}$ of soil in $30 \mathrm{~min}$, when measured at the plot scale. Despite being tilled with high frequency, runoff and sediment concentration were lower in the vineyard compared to the olive orchard. This can be attributed to the soil roughness and porosity due to frequent tillage.

Historically, tillage is recognized as a significant cause of soil erosion since agriculture was developed [50] and acts as a driving factor for the acceleration of soil loss in vineyards and orchards [5,51-53]. The application of herbicides in the olive orchard may have contributed to the increase in soil erosion. Keestra et al. [4] reported that herbicides have a higher impact on soil erodibility than tillage. High runoff and soil losses on herbicide plots in different land-use treatments were also measured [54-56].

VC was the lowest in the vineyard as a consequence of frequent tillage and compensates its adverse effects on plant cover and soil structure, and thus on infiltration, explaining the low erosion rates compared to the olive orchard plots. The highest runoff and soil loss were observed in the olive orchard and can be attributed to several reasons. The percentage of VC in the olive orchard plots is relatively small (20\%) to protect the soil. According to Cerda [57] soils, only $20 \%$ of cover can be described as bare. In soils where the cover was between $40 \%$ to $60 \%$, the erosion rates are much lower [57] compared to bare soils $(0-20 \mathrm{CV})$. In this context, VC reduced the soil erosion substantially, declining from $30-35 \mathrm{t} \mathrm{ha}^{-1}$ at $0 \%$ vegetative cover to $9 \mathrm{tha}^{-1}$ and $0.5 \mathrm{t} \mathrm{ha}^{-1}$ at $20 \%$ and $47 \%$ cover, respectively [58]. Similar findings were reported elsewhere. Hou et al. [59] observed that after a rainfall simulation $\left(60 \mathrm{~mm} \mathrm{~h}^{-1}\right)$, soil erosion was reduced by $55 \%, 90 \%$, and $100 \%$, when VC was $30 \%, 60 \%$, and $90 \%$, respectively. In cropland, VC reduced the effect of splash erosion, as reported in previous works $[1,4,5,9,10,60]$, contributed to the absence of runoff and erosion. Previous research highlighted that soil loss is reduced when VC is at least 40\% [57-59]. Finally, the incorporation of olive pomace organic matter in olive orchard soils may have increased the amount of hydrophobic compounds as observed elsewhere $[45,61]$.

PCA analysis supports the results described above. Factor 1 explained the majority of the erosion variables, and it is clearly observed that erosion was different between the olive orchard and vineyard and cropland. The values of TR, TP, BD, and VC were higher in the vineyard and cropland than in the olive orchard. The high TR and TP in soils with high BD, may be attributed to the vertic properties of the soil, as discussed previously. In opposition, the C loss, N loss, P loss, run, SL, and SC were high in 
the olive orchard plots. Erosion was substantially higher in the olive orchard compared to the other plots. On the other hand, Factor 2 was mainly related to $\mathrm{SC}, \mathrm{WHC}$, and $\mathrm{P}_{2} \mathrm{O}_{5}$ which was high in the vineyard and olive orchard. The opposite was identified in WSA.

Overall, despite the better soil conditions in olive orchard soils (low BD and high SWC, WSA, SOM, and $\mathrm{TN}$ ), Run and erosion rates were high as a consequence of the disruption of water preferential flow with tillage practices, herbicides application, reduced vegetation cover and organic matter properties. Less tilled soils (cropland) are more resistant to Run and sediment detachment as a consequence of the low disturbance and high VC. This work highlighted the necessity to carry out integrate studies (soil properties and hydrological response) in order to have a better understanding of long term management impacts.

\section{Conclusions}

Long term soil management produced substantial impacts on soil properties and hydrological response in the studied plots. The tillage practices in the vineyard likely decreased soil BD and increased WHC. The application of organic fertilizers in the olive orchard most likely increased soil quality. Nevertheless, tillage management in soils with vertic properties, the application of herbicides probably reduced $\mathrm{VC}$, and hydrophobic organic material apparently increased the overland flow and sediment and nutrient losses. Soil in the cropland area with minimal disturbance had a high infiltration and resistance to soil detachment, and this shows that less frequent tillage and cover crops probably increased soil resistance to rainfall impact. From a hydrological response perspective, the practices applied in the vineyard and olive orchard need to be reconsidered. The outcomes of this work showed that management practices should reduce tillage frequency and increase soil cover in order to decrease erosion. The present study contributes to better land-use management in Istria, although conclusions from a single measurement can be a limitation. Therefore, temporal studies will be considered in the future in order to have a clearer picture of management practices on soil and hydrological response.

Supplementary Materials: The following are available online at http://www.mdpi.com/2073-4395/10/2/282/s1.

Author Contributions: Conceptualization, B.I.; methodology, B.I.; validation, B.I. and T.L.J.; formal analysis, T.L.J. and P.P.; investigation, B.I.; writing-original draft preparation, B.I.; writing-review and editing, P.P., T.L.J.; visualization, P.P.; supervision, B.I. and P.P.; project administration, B.I.; funding acquisition, B.I. All authors have read and agreed to the published version of the manuscript.

Funding: This work was supported by Croatian Science Foundation through the project "Soil erosion and degradation in Croatia" (UIP-2017-05-7834) (SEDCRO).

Acknowledgments: Aleksandra Percin is acknowledged for her cooperation during the laboratory work.

Conflicts of Interest: The authors declare no conflict of interest.

\section{References}

1. Bogunovic, I.; Fernández, M.P.; Kisic, I.; Marimón, M.B. Agriculture and grazing environments. In Soil Degradation, Restoration and Management in a Global Change Context, 1st ed.; Pereira, P., Ed.; Elsevier: London, UK, 2019; Volume 4, pp. 23-70.

2. Taguas, E.V.; Gómez, J.A. Vulnerability of olive orchards under the current CAP (Common Agricultural Policy) regulations on soil erosion: A study case in Southern Spain. Land Use Policy 2015, 42, $683-694$. [CrossRef]

3. García-Díaz, A.; Allas, R.B.; Gristina, L.; Cerdà, A.; Pereira, P.; Novara, A. Carbon input threshold for soil carbon budget optimization in eroding vineyards. Geoderma 2016, 271, 144-149. [CrossRef]

4. Keesstra, S.; Pereira, P.; Novara, A.; Brevik, E.C.; Azorin-Molina, C.; Parras-Alcántara, L.; Jordán, A.; Cerdà, A. Effects of soil management techniques on soil water erosion in apricot orchards. Sci. Total Environ. 2016, 551, 357-366. [CrossRef]

5. Rodrigo-Comino, J. Five decades of soil erosion research in "terroir". The State-of-the-Art. Earth-Sci. Rev. 2018, 179, 436-447. [CrossRef] 
6. Prosdocimi, M.; Cerda, A.; Tarolli, P. Soil water erosion on Mediterranean vineyards: A review. Catena 2016, 141, 1-21. [CrossRef]

7. Gómez, J.A.; Campos, M.; Guzmán, G.; Castillo-Llanque, F.; Vanwalleghem, T.; Lora, Á.; Giráldez, J.V. Soil erosion control, plant diversity, and arthropod communities under heterogeneous cover crops in an olive orchard. Environ. Sci. Pollut. Res. 2018, 25, 977-989. [CrossRef] [PubMed]

8. Bogunovic, I.; Pereira, P.; Kisic, I.; Sajko, K.; Sraka, M. Tillage management impacts on soil compaction, erosion and crop yield in Stagnosols (Croatia). Catena 2018, 160, 376-384. [CrossRef]

9. Pereira, P.; Bogunovic, I.; Muñoz-Rojas, M.; Brevik, E.C. Soil ecosystem services, sustainability, valuation and management. Curr. Opin. Environ. Sci. Health 2018, 5, 7-13. [CrossRef]

10. Almagro, M.; De Vente, J.; Boix-Fayos, C.; García-Franco, N.; De Aguilar, J.M.; González, D.; Solé-Benet, A.; Martínez-Mena, M. Sustainable land management practices as providers of several ecosystem services under rainfed Mediterranean agroecosystems. Mitig. Adapt. Strat. Gl. 2016, 21, 1029-1043. [CrossRef]

11. Blevins, R.L.; Lal, R.; Doran, J.W.; Langdale, G.W.; Frye, W.W. Conservation tillage for erosion control and soil quality. In Advances in Soil and Water Conservation, 1st ed.; Pierce, F.J., Ed.; Routledge: New York, NY, USA, 2018; Volume 4, pp. 51-68.

12. Capello, G.; Biddoccu, M.; Ferraris, S.; Cavallo, E. Effects of Tractor Passes on Hydrological and Soil Erosion Processes in Tilled and Grassed Vineyards. Water 2019, 11, 2118. [CrossRef]

13. Dekemati, I.; Bogunovic, I.; Kisic, I.; Radics, Z.; Szemők, A.; Birkás, M. The Effects of Tillage-Induced Soil Disturbance on Soil Quality Condition. Pol. J. Environ. Stud. 2019, 5, 3665-3673. [CrossRef]

14. Bogunović, I.; Kisić, I.; Mesić, M.; Zgorelec, Ž.; Šestak, I.; Perčin, A.; Bilandžija, D. Sustainable Soil Management Measures in Organic Agriculture for Climate Conditions of Mediterranean Croatia, 1st ed.; University of Zagreb Faculty of Agriculture: Zagreb, Croatia, 2018; p. 147.

15. Paroissien, J.P.; Darboux, F.; Couturier, A.; Devillers, B.; Moulliot, F.; Raclot, D.; Le Bissonnais, Y. A method for modeling the effects of climate and land use changes on erosion and sustainability of soil in a Mediterranean watershed (Languedoc, France). J. Environ. Manag. 2015, 150, 57-58. [CrossRef] [PubMed]

16. Garcia-Ruiz, J.M.; Bergueria, S.; Lana-Renault, N.; Nadal-Romero, E.; Cerda, A. Ongoing and Emerging Questions in Water Erosion Studies. Land Degrad. Dev. 2017, 28, 5-71. [CrossRef]

17. Nadal-Romero, E.; Lasanta, T.; Cerda, A. Integrating Extensive Livestock and Soil Conservation Policies in Mediterranean Mountain Areas for Recovery of Abandoned Lands in the Central Spanish Pyrenees. A Long-Term Research Assessment. Land Degrad. Dev. 2018, 29, 262-273. [CrossRef]

18. Basic, F.; Kisic, I.; Mesic, M.; Nestroy, O.; Butorac, A. Tillage and crop management effects on soil erosion in central Croatia. Soil Till. Res. 2004, 78, 197-206. [CrossRef]

19. Kisić, I.; Bogunović, I.; Birkás, M.; Jurišić, A.; Spalević, V. The role of tillage and crops on a soil loss of an arable Stagnic Luvisol. Arch. Agron. Soil Sci. 2017, 63, 403-413. [CrossRef]

20. IUSS Working Group WRB. World Reference Base for Soil Resources 2014, Update 2015: International Soil Classification System for Naming Soils and Creating Legends for Soil Maps; World Soil Resources Reports No. 106; FAO: Rome, Italy, 2015; p. 192.

21. Kottek, M.; Grieser, J.; Beck, C.; Rudolf, B.; Rubel, F. World map of the Köppen-Geiger climate classification updated. Meteorol. Z. 2006, 15, 259-263. [CrossRef]

22. Biddoccu, M.; Ferraris, S.; Opsi, F.; Cavallo, E. Long-term monitoring of soil management effects on runoff and soil erosion in sloping vineyards in Alto Monferrato (North-West Italy). Soil Till Res. 2016, 155, 176-189. [CrossRef]

23. Veihmeyer, F.J.; Hendrickson, A.H. The moisture equivalent as a measure of the field capacity of soils. Soil Sci. 1931, 32, 181-194. [CrossRef]

24. Black, C.A. Method of Soil Analysis. Part 2. Chemical and Microbiological Properties, 1st ed.; American Society of Agronomy, Inc.: Madison, WI, USA, 1965; pp. 771-1569.

25. Diaz-Zorita, M.; Perfect, E.; Grove, J.H. Disruptive methods for assessing soil structure. Soil Till. Res. 2002, 64, 3-22. [CrossRef]

26. Le Bissonnais, Y.L. Aggregate stability and assessment of soil crustability and erodibility: I. Theory and methodology. Eur. J. Soil. Sci. 1996, 47, 425-437. [CrossRef]

27. Kemper, W.D.; Rosenau, R.C. Aggregate stability and size distribution. In Methods of Soil Analysis, Part 1. Physical and Mineralogical Methods, 2nd ed.; Klute, A., Ed.; American Society of Agronomy: Madison, WI, USA, 1986; Volume 1, pp. 425-442. 
28. Walkly, A.; Black, I.A. An examination of digestion methods for determining soil organic matter and a proposed modification of the chromic and titration. Soil Sci. Soc. Am. J. 1934, 37, 29-38. [CrossRef]

29. Egnér, H.A.N.S.; Riehm, H.; Domingo, W.R. Untersuchungen über die chemische Bodenanalyse als Grundlage für die Beurteilung des Nährstoffzustandes der Böden. II. Chemische Extraktionsmethoden zur Phosphor-und Kaliumbestimmung. Lantbrukshögskolans Ann. 1960, 26, 199-215.

30. Holman, W.I.M. A new technique for the determination of phosphorus by the molybdenum blue method. Biochem. J. 1943, 37, 256. [CrossRef]

31. Plotly. Available online: https://chart-studio.plot.ly/ (accessed on 16 November 2019).

32. Krzic, M.; Fortin, M.C.; Bomke, A.A. Short-term responses of soil physical properties to corn tillage-planting systems in a humid maritime climate. Soil Till. Res. 2000, 54, 171-178. [CrossRef]

33. Salem, H.M.; Valero, C.; Munoz, M.A.; Rodriguez, M.G.; Silva, L.L. Short-term effects of four tillage practices on soil physical properties, soil water potential, and maize yield. Geoderma 2015, 237-238, 60-70. [CrossRef]

34. Håkansson, I. Machinery-Induced Compaction of Arable Soils (No. 109), 1st ed.; Institutionen för markvetenskap, Avdelningen för jordbearbetning: Uppsala, Sweden, 2005; p. 153.

35. Materechera, S.A. Tillage and tractor traffic effects on soil compaction in horticultural fields used for peri-urban agriculture in a semi-arid environment of the North West Province, South Africa. Soil Till. Res. 2009, 103, 11-15. [CrossRef]

36. Gao, X.; Wu, P.; Zhao, X.; Wang, J.; Shi, Y. Effects of land use on soil moisture variations in a semi-arid catchment: Implications for land and agricultural water management. Land Degrad. Dev. 2014, 25, 163-172. [CrossRef]

37. Bewket, W.; Stroosnijder, L. Effects of agroecological land use succession on soil properties in Chemoga watershed, Blue Nile basin, Ethiopia. Geoderma 2003, 111, 85-98. [CrossRef]

38. Celik, I. Land-use effects on organic matter and physical properties of soil in a southern Mediterranean highland of Turkey. Soil Till. Res. 2005, 83, 270-277. [CrossRef]

39. Tanner, S.; Katra, I.; Argaman, E.; Ben-Hur, M. Erodibility of waste (Loess) soils from construction sites under water and erosional forces. Sci. Total Environ. 2018, 616-617, 1524-1532. [CrossRef]

40. Zhang, S.; Grip, H.; Lövdahl, L. Effect of soil compaction on hydraulic properties of two loess soils in China. Soil Till. Res. 2006, 90, 117-125. [CrossRef]

41. Kay, B.D. Soil structure and organic carbon: A review. In Soil Processes and the Carbon Cycle, 1st ed.; Lal, R., Kimble, J.M., Follett, R.F., Stewart, B.A., Eds.; CRC Press: Boca Raton, FL, USA, 2018; pp. 169-197.

42. Doetterl, S.; Berhe, A.A.; Nadeu, E.; Wang, Z.; Sommer, M.; Fiener, P. Erosion, deposition and soil carbon: A review of process-level controls, experimental tools and models to address $\mathrm{C}$ cycling in dynamic landscapes. Earth-Sci. Rev. 2016, 154, 102-122. [CrossRef]

43. Aranda, V.; Macci, C.; Peruzzi, E.; Masciandaro, G. Biochemical activity and chemical-structural properties of soil organic matter after 17 years of amendments with olive-mill pomace co-compost. J. Environ. Manag. 2015, 147, 278-285. [CrossRef] [PubMed]

44. Chaplot, V.; Abdalla, K.; Alexis, M.; Bourennane, H.; Darboux, F.; Dlamini, P.; Everson, C.; Mchunu, C.; Muller-Nedebock, D.; Mutema, M.; et al. Surface organic carbon enrichment to explain greater $\mathrm{CO}_{2}$ emissions from short-term no-tilled soils. Agric. Ecosyst. Environ. 2015, 203, 110-118. [CrossRef]

45. Lozano-García, B.; Parras-Alcántara, L. Short-term effects of olive mill by-products on soil organic carbon, total N, C: N ratio and stratification ratios in a Mediterranean olive grove. Agric. Ecosyst. Environ. 2013, 165, 68-73. [CrossRef]

46. Ali, G.; Macrae, M.; Walker, M.; Laing, J.; Lobb, D. Preferential Flow in Vertisolic Soils with and without Organic Amendments. Agric. Environ. Lett. 2018, 3, 180018. [CrossRef]

47. Fuhrman, I.; Maarastawi, S.; Neumann, J.; Arnelung, W.; Frindte, K.; Knief, C.; Lehndorff, E.; Wassman, R.; Siemens, S. Preferential flow pathways in paddy rice soils as hot spots for nutrient cycling. Geoderma 2019, 337, 594-606. [CrossRef]

48. Potter, K.N.; Torbert, H.A.; Morrison, J.S., Jr. Tillage and Residue Effects on Infiltration and Sediment Losses on Vertisols. Trans. ASAE 1995, 38, 1413-1419. [CrossRef]

49. Carroll, C.; Halpin, M.; Burger, P.; Bell, K.; Sallaway, M.M.; Yule, D.F. The effect of crop type, crop rotation, and tillage practice on runoff and soil loss on a Vertisol in central Queensland. Aust. J. Soil Res. 1997, 35, 925-940. [CrossRef] 
50. Lal, R.; Reicosky, D.C.; Hanson, J.D. Evolution of the plow over 10,000 years and the rationale for no-till farming. Soil Till. Res. 2007, 93, 1-12. [CrossRef]

51. Battany, M.C.; Grismer, M.E. Rainfall runoff and erosion in Napa Valley vineyards: Effects of slope, cover and surface roughness. Hydrol. Process. 2000, 14, 1289-1304. [CrossRef]

52. Laker, M.C. Advances in soil erosion, soil conservation, land suitability evaluation and land use planning research in South Africa, 1978-2003. S. Afr. J. Plant Soil 2004, 21, 345-368. [CrossRef]

53. Anache, J.A.; Wendland, E.C.; Oliveira, P.T.; Flanagan, D.C.; Nearing, M.A. Runoff and soil erosion plot-scale studies under natural rainfall: A meta-analysis of the Brazilian experience. Catena 2017, 152, 29-39. [CrossRef]

54. Gómez, J.A.; Sobrinho, T.A.; Giráldez, J.V.; Fereres, E. Soil management effects on runoff, erosion and soil properties in an olive grove of Southern Spain. Soil Till. Res. 2009, 102, 5-13. [CrossRef]

55. García-Orenes, F.; Roldán, A.; Mataix-Solera, J.; Cerdà, A.; Campoy, M.; Arcenegui, V.; Caravaca, F. Soil structural stability and erosion rates influenced by agricultural management practices in a semi-arid Mediterranean agro-ecosystem. Soil Use Manag. 2012, 28, 571-579. [CrossRef]

56. Liu, H.; Blagodatsky, S.; Giese, M.; Liu, F.; Xu, J.; Cadisch, G. Impact of herbicide application on soil erosion and induced carbon loss in a rubber plantation of Southwest China. Catena 2016, 145, 180-192. [CrossRef]

57. Cerda, A. Parent material and vegetation affect soil erosion in eastern Spain. Soil Sci. Soc. Am. J. 1999, 63, 362-368. [CrossRef]

58. Loch, R.J. Effects of vegetation cover on runoff and erosion under simulated rain and overland flow on a rehabilitated site on the Meandu Mine, Tarong, Queensland. Soil Res. 2000, 38, 299-312. [CrossRef]

59. Hou, G.; Bi, H.; Huo, Y.; Wei, X.; Zhu, Y.; Wang, X.; Liao, W. Determining the optimal vegetation coverage for controlling soil erosion in Cynodon dactylon grassland in North China. J. Clean. Prod. 2020, 244, 118771. [CrossRef]

60. Panagos, P.; Borrelli, P.; Poesen, J.; Ballabio, C.; Lugato, E.; Meusburger, K.; Montanarella, L.; Alewell, C. The new assessment of soil loss by water erosion in Europe. Environ. Sci. Policy 2015, 54, 438-447. [CrossRef]

61. Bughici, T.; Wallach, R. Formation of soil-water repellency ino live orchards and its influence on infiltration pattern. Geoderma 2016, 262, 1-11. [CrossRef]

(C) 2020 by the authors. Licensee MDPI, Basel, Switzerland. This article is an open access article distributed under the terms and conditions of the Creative Commons Attribution (CC BY) license (http://creativecommons.org/licenses/by/4.0/). 